\title{
Extraocular muscle surgery in myasthenia gravis
}

\author{
J F Acheson, J S Elston, J P Lee, P Fells
}

\begin{abstract}
Myasthenia gravis is typically a disease of young people in active employment who need a field of binocular single vision. Although it is systemically controllable with a good chance of spontaneous remission, persistent loss of binocularity may cause chronic disability. We report our experience of extraocular muscle surgery in five patients with stable myasthenia gravis and persistent double vision. Extraocular muscle involvement was selective, giving rise to incomitant and concomitant squints, with individual muscle overactions as well as underactions. Treatment was by conventional recession and resection procedures with the additional use of Faden and adjustable sutures where appropriate. In all five cases a larger, stable field of binocular single vision was established. It is concluded that extraocular muscle surgery may be beneficial in selected cases of myasthenia gravis.
\end{abstract}

Western Ophthalmic Hospital, London NW1 $\mathrm{J} F$ Acheson J S Elston

National Hospital for Neurology and Neurosurgery, London WC1

J S Elston

Moorfields Eye Hospital, London ECl

J P Lee

P Fells

Correspondence to

JF Acheson, FRCS, Western Ophthalmic Hospital, Marylebone Road, London NW1 5 YE.

Accepted for publication 22 October 1990

Myasthenia gravis (MG) is an autoimmune disorder characterised by a reduction in available post-synaptic acetylcholine receptors (AChR) on the endplates of neuromuscular junctions of skeletal muscle.' The symptoms of variable, fatiguable voluntary muscle weakness with spontaneous remissions and exacerbations are well known. In $75 \%$ of cases the initial presentation is with ptosis and/or diplopia, and over $90 \%$ develop ophthalmic symptoms at some stage in the course of the disease. Diagnosis is often delayed because ocular motility abnormalities may mimic other conditions and because no single test is always positive. ${ }^{2}$ Young people with long life expectancies are commonly affected and ocular motility abnormalities causing disabling diplopia and loss of binocular single vision (BSV) may persist long after remission. Conventionally

Table 1 Diagnostic features

\begin{tabular}{|c|c|c|c|c|c|}
\hline \multicolumn{3}{|c|}{ Patients } & \multirow[b]{2}{*}{ Edrophonium } & \multirow[b]{2}{*}{$\begin{array}{l}\text { Anti-AChR } \\
\text { antibodies }\end{array}$} & \multirow[b]{2}{*}{$S F E M G$} \\
\hline No. & Sex & $\begin{array}{l}\text { Age at } \\
\text { presentation }\end{array}$ & & & \\
\hline $\begin{array}{l}1 \\
2 \\
3 \\
4 \\
5\end{array}$ & $\begin{array}{l}M \\
M \\
F \\
M \\
M\end{array}$ & $\begin{array}{l}22 \\
25 \\
19 \\
16 \\
52\end{array}$ & $\begin{array}{l}+ \\
+ \\
+ \\
+ \\
+\end{array}$ & $\begin{array}{l}+ \\
+ \\
+ \\
+ \\
+\end{array}$ & $\begin{array}{l}\text { Normal } \\
\text { Normal } \\
\text { Normal } \\
\text { Abnormal } \\
\text { Normal }\end{array}$ \\
\hline
\end{tabular}

Table 2 Systemic treatment

\begin{tabular}{llllc}
\hline No. Patients & Anticholinesterases & Thymectomy & $\begin{array}{l}\text { Immunosuppression } \\
\text { (oral steroids) }\end{array}$ & $\begin{array}{l}\text { Years } \\
\text { stable }\end{array}$ \\
\hline 1 & Yes & Yes & Yes & 2 \\
2 & Yes & Yes & No & 10 \\
3 & Yes & Yes & No & 22 \\
4 & Yes & No & Yo & 2 \\
5 & Yes & No & Yes & 2 \\
\hline
\end{tabular}

this is managed by prisms or occlusion, ${ }^{3-6}$ but these measures may be poorly tolerated and leave unacceptable cosmetic results. In addition, loss of BSV may limit employment opportunities.

We report on five patients with stable systemic disease but in whom persistent unchanging diplopia left poor results. All benefited from extraocular muscle surgery.

\section{Materials and methods}

Five cases were identified from the records of the ocular motility clinics at the Western Ophthalmic Hospital and Moorfields Eye Hospital. All had a clinical diagnosis of $M G$ confirmed by a positive edrophonium test and/or characteristic jitter phenomena on the electromyogram, together with the presence of anti-acetylcholine receptor antibodies. All were clinically and biochemically euthyroid, and cases with features suggesting coexisting dysthyroid ophthalmopathy were excluded. No cases had a thymic or other neoplasm, or evidence of connective tissue disease. All patients were symptomatically in disease remission but complained of troublesome, constant diplopia. None had clinically significant ptosis. After a minimum two-year period of stable orthoptic assessments and failure to tolerate prisms or monocular occlusion, extraocular muscle surgery was performed. All cases were followed up for a period of six months to six years after surgery. The clinical details are summarised on Tables 1 and 2 .

\section{Results}

The cases are summarised on Table 3. Two are reported in detail.

\section{CASE 1}

In 1981 a fireman aged 22 years presented with variable fatiguable diplopia and limb and facial weakness. Following an equivocal response to intravenous edrophonium (Tensilon), generalised myasthenia gravis was diagnosed on the basis of positive titres for anticholinesterase receptor (AChR) antibodies and an electromyogram which showed muscle fibre fatigue on supramaximal nerve stimulation at $3-5 \mathrm{~Hz}$. The systemic symptoms were controlled by thymectomy for thymic hyperplasia and oral pyridostigmine. However, troublesome horizontal diplopia persisted, and in 1983 he was referred for assessment.

The visual acuities and findings on intraocular examination were normal. There was a $3 \mathrm{~mm}$ ptosis on the right and mild bilateral orbicularis weakness. The prism cover test showed a V pattern exotropia of 6 dioptres on downgaze and 20 dioptres on elevation. Dissociated eye movement analysis (Fig 1A) indicated marked right 
Table 3 Summary of ocular motility findings and surgical procedures

\begin{tabular}{|c|c|c|c|c|c|}
\hline Patient & Eye movements & $\begin{array}{l}\text { BSV field } \\
\text { (degrees) }\end{array}$ & Operation & $\begin{array}{l}B S V \\
\text { field }\end{array}$ & $\begin{array}{l}\text { Years stable } \\
\text { follow-up }\end{array}$ \\
\hline 1 & $\begin{array}{l}\text { 10 dioptre exotropia } \\
\text { R: MR underaction } \\
\text { L: LR overaction } \\
\text { 5-Dioptre left hypertropia }\end{array}$ & $30^{\circ}$ & L: LR Faden & 80 & 6 \\
\hline \multirow[t]{2}{*}{2} & $\begin{array}{l}\text { 45-Dioptre exotropia } \\
\text { L: MR underaction }\end{array}$ & Nil & (i) $\begin{aligned} & L: L R-6 \\
& M R+5\end{aligned}$ & 40 & 2 \\
\hline & & & $\begin{array}{l}\text { (ii) L: SO } \\
\text { posterior tenotomy }\end{array}$ & 50 & \\
\hline 3 & $\begin{array}{l}\text { 60-Dioptre exotropia } \\
\text { R:MR underaction } \\
\text { 10-Dioptre left hypertropia }\end{array}$ & Nil & $\begin{aligned} R: & L R-9.5 \\
& M R+10\end{aligned}$ & $\begin{array}{l}30 \\
\text { with prisms }\end{array}$ & 1 \\
\hline 4 & $\begin{array}{l}\text { A pattern esotropia } \\
55 \text { dioptres upgaze } \\
10 \text { dioptres downgaze } \\
\text { bilateral SO overaction } \\
\text { bilateral IR underaction }\end{array}$ & Nil & $\begin{array}{l}\text { (i) Bilateral } M R-5 \\
\text { and SO posterior } \\
\text { tenotomies }\end{array}$ & 30 & 2 \\
\hline 5 & $\begin{array}{l}\text { (1) 45-Dioptre exotropia } \\
\text { right hypotropia } \\
\text { ? IIIrd nerve palsy }\end{array}$ & Nil & $\begin{array}{l}\text { (ii) Bilateral MR } \\
\text { superposition } \\
\text { (i) R: LR-, MR+ }\end{array}$ & 40 & 1 \\
\hline & $\begin{array}{l}\text { (2) Consecutive esotropia } \\
\text { 30 dioptres } \\
\text { R: LR underaction }\end{array}$ & & (ii) $\mathbf{R}: \begin{array}{l}\mathbf{L R}+7 \\
M R-2(\text { adj) }\end{array}$ & 30 & 1 \\
\hline
\end{tabular}

$R=$ right. $L=$ left. $M R=$ medial rectus. $L R=$ lateral rectus. $I R=$ inferior rectus. $S O=$ superior oblique adj=adjustable suture. $-=$ rectus recession $(\mathrm{mm}) .+=$ rectus resection $(\mathrm{mm})$. BSV $=$ field of binocular single vision.

medial rectus underaction and left lateral rectus overaction. The field of binocular single vision (BSV) was reduced to $30^{\circ}$ (Fig $1 \mathrm{~B}$ ).

After a 12-month period of observation the

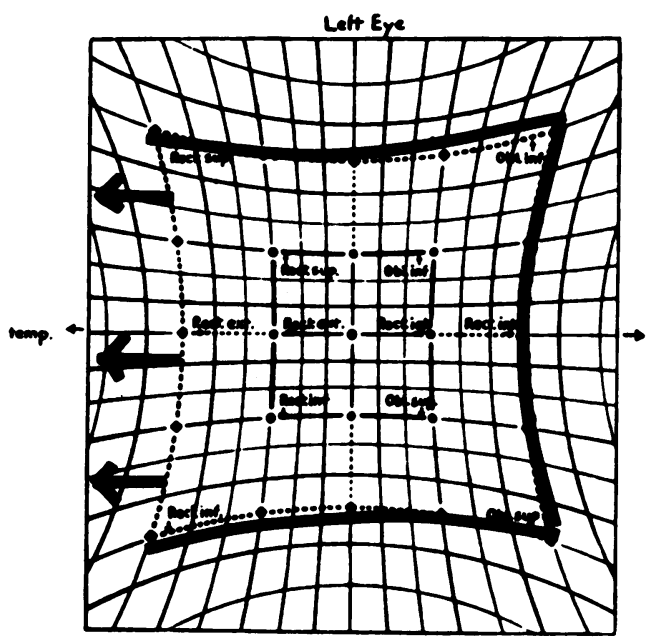

Green before helt ere motility abnormalities were unchanged and the systemic disease remained controlled. The patient was unable to tolerate prisms or occlusion and following a normal forced duction test

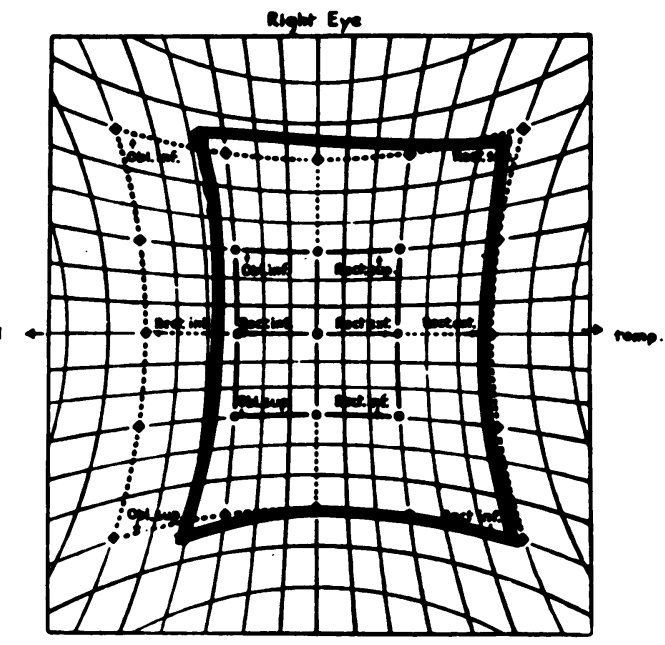

Green before inght ove

Figure $1 A$ Hess chart showing exotropia with right medial rectus underaction and left lateral rectus overaction.

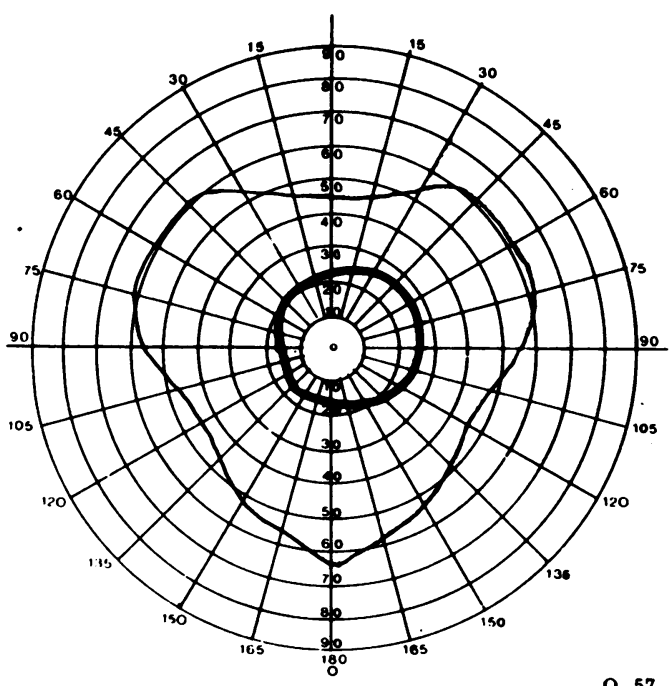

GIELD OF BINOCULAR fixailon. No.

O. 57

Figure $1 B$ Field of binocular single vision before surgical treatment. underwent a left lateral rectus Faden posterior fixation suture operation. The field of binocular single vision was increased to $80^{\circ}$ arc (Fig 1C, D), and this improvement has been stable over six years of follow-up.

CASE 4

In 1984 a 16--year-old male college student developed diplopia, and a diagnosis of generalised myasthenia was made after detection of AChR antibodies and deltoid electromyographic abnormalities. Disease activity was controlled by oral prednisolone on alternate days, but a large angle convergent squint persisted.

In 1988 he was referred for assessment. This showed a large A pattern esotropia of 55 dioptres on downgaze and 10 dioptres on upgaze. Ocular movements showed marked bilateral superior oblique overactions and inferior rectus underactions (Fig 2A). There was no field of BSV. 
Figure 1C Hess chart after Faden procedure to left lateral rectus.

Figure $1 D$ Field of binocular single vision after left lateral rectus Faden procedure.
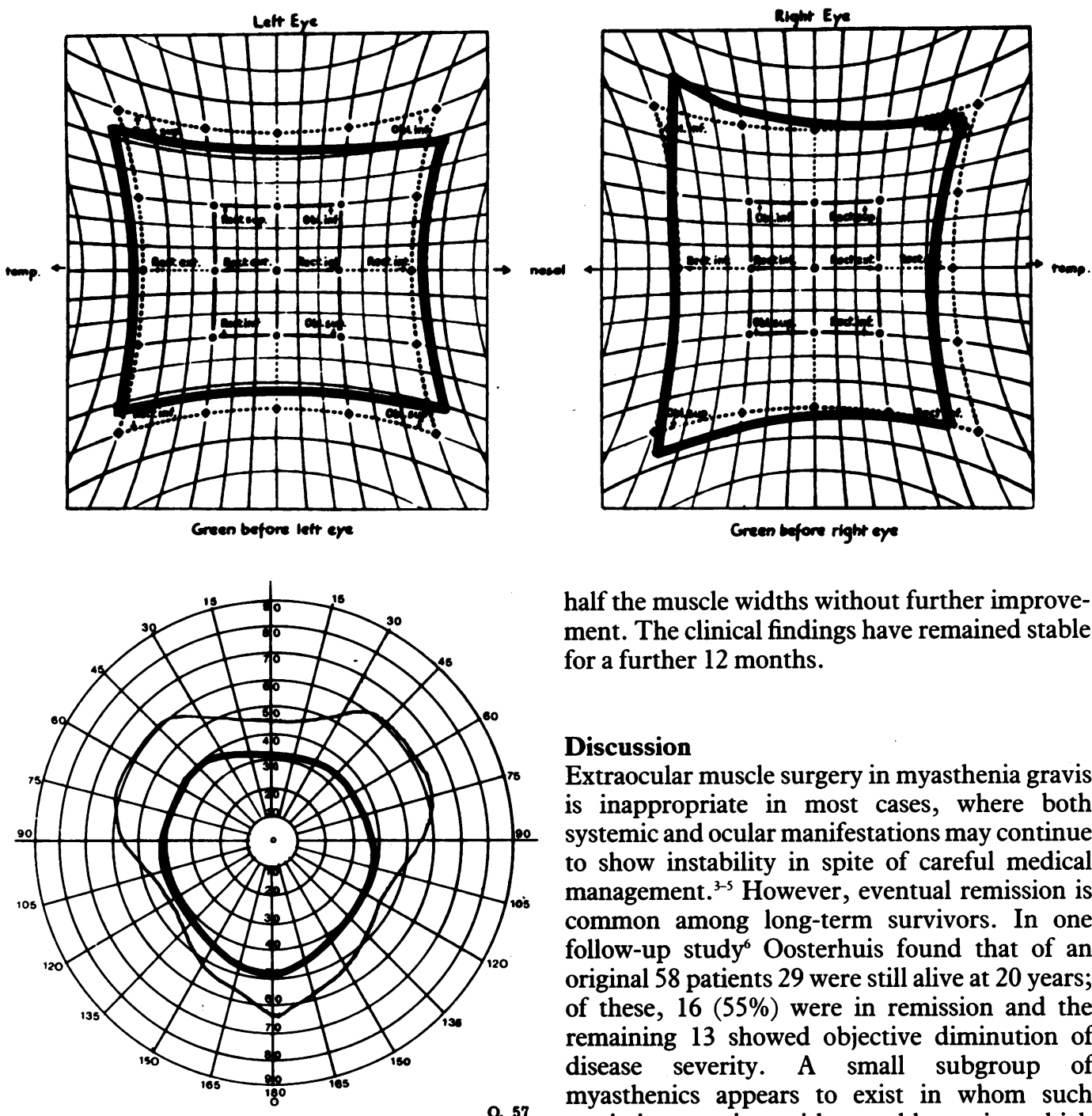

Field of BinoculaA fixation. No.

O. 57

Over the next 12 months the strabismus remained unchanged, and his systemic disease was stable.

In January 1989 he underwent bilateral medial rectus recessions of $5 \mathrm{~mm}$ and bilateral superior oblique posterior 7/8 tenotomies. Postoperatively a BSV field of $30^{\circ}$ was established, but the A pattern persisted with a 40 dioptres of esotropia on elevation and 5 dioptres on depression (Fig 2B). Six months later he underwent bilateral medial rectus insertion elevations by

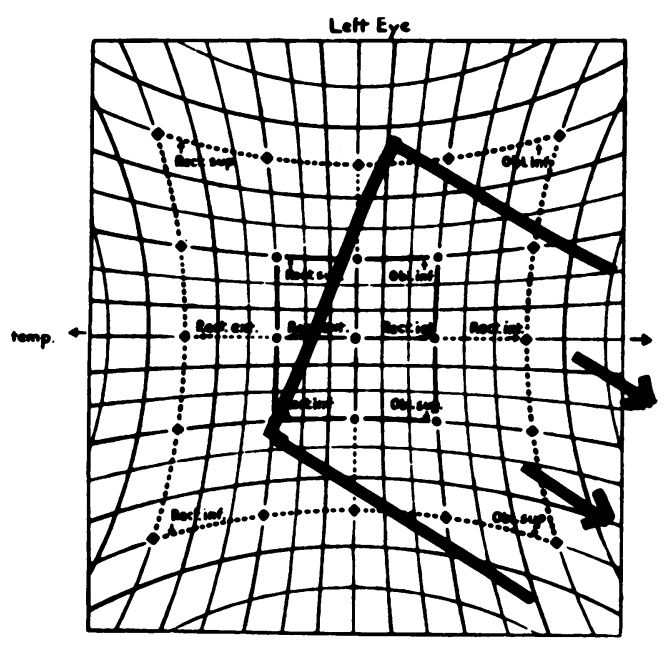

creen before left eye half the muscle widths without further improvement. The clinical findings have remained stable for a further 12 months.

\section{Discussion}

Extraocular muscle surgery in myasthenia gravis is inappropriate in most cases, where both systemic and ocular manifestations may continue to show instability in spite of careful medical management. ${ }^{3-5}$ However, eventual remission is follow-up study ${ }^{6}$ Oosterhuis found that of an original 58 patients 29 were still alive at 20 years; of these, $16(55 \%)$ were in remission and the remaining 13 showed objective diminution of disease severity. A small subgroup of myasthenics appears to exist in whom such remission coexists with a stable squint which may limit rehabilitation opportunities. This is the category into which our five cases fit.

Ocular motility analysis (Table 3 and Figs 1 and 2) shows that individual muscle involvement was highly selective and that secondary overactions were common. This clinical observation has not to our knowledge been previously described. However, electrophysiological and histological studies do support our observation of highly selective, variable involvement of muscles in myasthenia gravis. ${ }^{2}$ Between one muscle and another the electromyogram may show variable

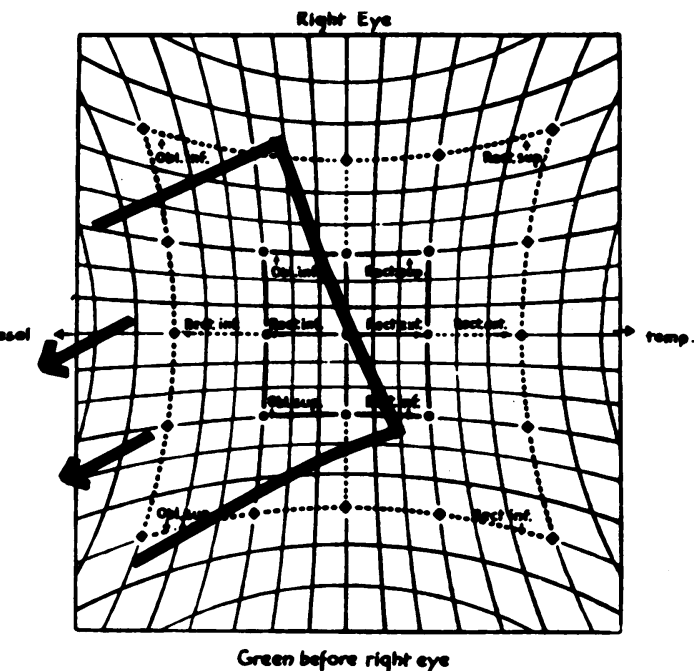
common among long-term survivors. In one 
Figure 2B Hess chart after bilateral superior oblique posterior tenotomies.
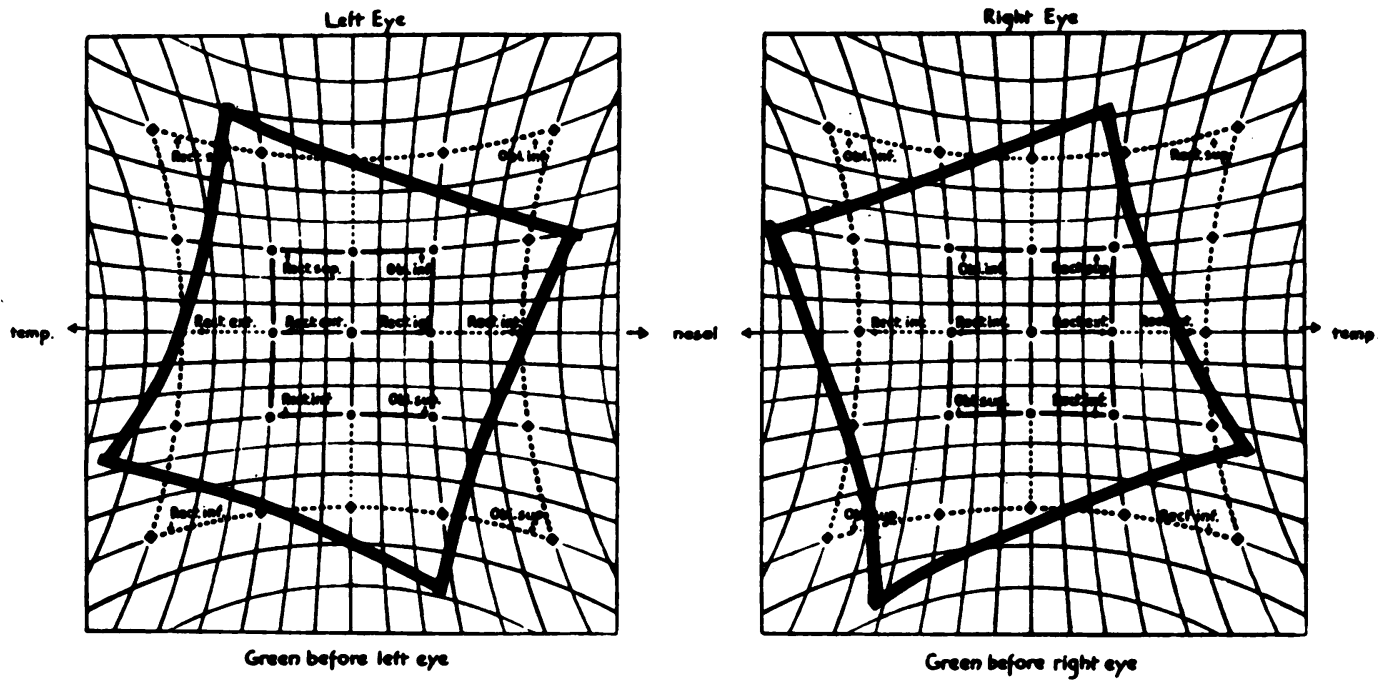

abnormal decremental responses of the evoked compound muscle action potential on repetitive nerve stimulation. Within one muscle the single fibre EMG may show characteristic jitter phenomena arising from variations in activation time on the action potentials of two fibres from the same motor unit. Similar variability is shown in AChR receptor densities in histopathological studies in muscle biopsy specimens. For these reasons, we have avoided surgery on 'weak' underacting muscles where possible and have performed weakening procedures on overacting relatively healthy muscles. Cases 1 and 4 were managed solely by this approach. For example, in the concomitant pattern seen in case 4 rectus muscle recession and transposition and superior oblique tenotomy were appropriate, ${ }^{7}$ while in the incomitant cases the Faden posterior fixation and recession on an adjustable suture were preferred. ${ }^{8-11}$ However, single rectus muscle resections were performed in cases 2,3 , and 5 with satisfactory results.

In conclusion, patients with a definite diagnosis of myasthenia gravis whose disease process is stable or in remission, but who continue to suffer from disabling diplopia and loss of binocularity, may safely and effectively be managed by extraocular muscle surgery.

We are grateful to the orthoptic staff at the Western Ophthalmic these cases.

1 Seybold ME. Myasthenia gravis: a clinical and basic science review. FAMA 1983; 250: 2516-21.

2 Oosterhuis HJGH. Myasthenia gravis. Clinical neurology and neuro-surgery monographs. Edinburgh: Churchill Livingneuro-surgery
stone, $1984: 5$.

3 Mein J, Harcourt B. Diagnosis and management of ocular motility disorders. Oxford: Blackwell, 1986: chapter 19: 324.

4 Glaser JS. Infranuclear disorders of eye movement. In: Duane TD, Jaeger EA, eds. Clinical ophthalmology. Philadelphia: Lipincott, 1988; 2: chapter 12: 31-7.

5 Miller NR. Myopathies and disorders of neuro-muscular transmission. Walsh and Hoyt's clinical neuro-ophthalmologv. 4th ed. St Louis: Mosby, 1987; 2: chapter 36: 859.

6 Oosterhuis HJGH. The natural course of myasthenia gravis: long term follow-up study. I Neurol Neurosurg Psychiatry 1989; 52: 1121-7.

7 Willshaw HE, O'Connor GM. Transposition surgery in childhood strabismus. Eye 1988; 2: 41-3.

8 Scott AB. The Faden operation: mechanical effects. Am Orthopt $\mathcal{F}$ 1984; 27: 44-7.

9 Harcourt B. Faden operation (posterior fixation sutures). Eye 1988; 2: 36-40.

10 Rosenblum AL, Metz HS, Carlson M, Jampolsky AL. Adjustable rectus muscle recession surgery. Arch Ophthalmol 1977 95: 817-20.

11 Fells P. The use of adjustable sutures. Trans Ophthalmol Soc UK 1981; 101: 279-83. Hospital and Moorfields Eye Hospital for the documentation of 